\title{
Antioxidant and Free Radical Scavenging Activities of Newbouldia laevis Leaf extracts
}

\author{
Aanuoluwa James Salemcity ${ }^{1,2, *}$, Victoria Obiageli Nwaneri-Chidozie ${ }^{3}$, Emmanuel Adameh ${ }^{3}$, \\ Magdalene Eno Effiong ${ }^{1,3}$
}

\section{Aanuoluwa James Salemcity ${ }^{1,2, *}$, Victoria Obiageli Nwaneri- Chidozie $^{3}$, Emmanuel Adameh $^{3}$, Magdalene Eno Effiong ${ }^{1,3}$}

'Department of Biochemistry, University of Ibadan, Oyo State, NIGERIA.

${ }^{2}$ University of Medical Sciences, Ondo State, NIGERIA.

${ }^{3}$ Department of Biochemistry, University of Ibadan, Oyo State, Salem University, Kogi State, NIGERIA.

\section{Correspondence}

Mr. Aanuoluwa James Salemcity

'Department of Biochemistry, University of Ibadan, Oyo State, NIGERIA.

2University of Medical Sciences, Ondo State, NIGERIA.

Phone no: 234-806-0406330

E-mail: xityglory@gmail.com

History

- Submission Date: 02-06-2020

- Review completed: 18-06-2020;

- Accepted Date: 30-07-2020.

DOI : 10.5530/fra.2020.1.3

Article Available online

http://www.antiox.org

Copyright

(C) 2020 Phcog.Net. This is an openaccess article distributed under the terms of the Creative Commons Attribution 4.0 International license.

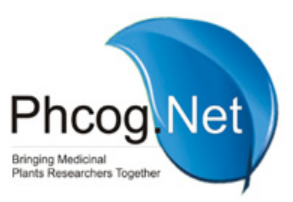

\begin{abstract}
Objectives: Oxidative stress is implicated in the etiology of life-threatening disease conditions. Newbouldia laevis (NL) have been used in folk medicine for stress related conditions, however, there is paucity of reports suggesting a connection between its efficacy and a possible antioxidant property. The aim of this study was to evaluate the antioxidant properties of NL leaf extracts. Methods: The methanol extract of NL was partitioned to obtain the chloroform fraction (CFNL) and the aqueous fraction (AFNL). Following standard laboratory procedures, the parameters were measured spectrophotometrically. Results: The MFNL recorded the highest activity for DPPH (76.4\%), while all extracts only showed slight hydrogen peroxide scavenging capacity. Total antioxidant capacity at uniform concentration revealed an increasing order of activity from AFNL to MENL, correlating with total phenol contents which is in the same order. Furthermore, the extracts inhibited lipid peroxidation in a concentration dependent manner, with MENL recording the highest inhibition of $19.5 \%$. The MENL however had the highest vitamin C concentration of $165.44 \mathrm{mg} / 100 \mathrm{ml}$. Conclusion: The above results not only demonstrate the antioxidant properties of $\mathrm{NL}$, but suggests this as one of its possible mechanism of action and indicates the presence of potent principles with potential for application in stress related ailments.
\end{abstract}

Key words: Newbouldia laevis, Oxidative stress, Vitamin C, Antioxidants, Lipid peroxidation.

\section{INTRODUCTION}

The maintenance of ROS (reactive oxygen species)/ antioxidant ratio is apparently very significant to the proper functioning of the living system. ${ }^{1}$ This balance is dependent on the physiologic and pathophysiologic states of the system. ${ }^{2}$ On the one hand, certain levels of ROS are essential for cell signaling and certain physiological events, while on the other hand, excessive generation of ROS has been identified as the catalyst of certain disease conditions which includes, among others, cancer, heart failure, diabetes, obesity, stroke and neurodegenerative diseases. ${ }^{3}$

ROS are generated by biochemical reactions in the cell. ${ }^{4}$ The Superoxide anion radical $\mathrm{O}_{2}{ }^{-}$is significantly produced by the enzymatic reactions of the mitochondrial electron transport chain, the TCA cycle enzymes a-ketoglutarate dehydrogenase complex, ${ }^{5}$ the NADPH oxidase enzyme of phagocytic and non-phagocytic macrophages and by xanthine dehydrogenase/oxidase. Hydrogen peroxides $\left(\mathrm{H}_{2} \mathrm{O}_{2}\right)$, are generated in the dismutation of $\mathrm{O}_{2}{ }^{-}-$by superoxide dismutases and also by mitochondrial monoamine oxidase. ${ }^{6}$ Hypochlorous acid $(\mathrm{HOCl})$ is formed by the reaction of myeloperoxidase released by activated phagocytes and $\mathrm{H}_{2} \mathrm{O}_{2}$ during oxidative burst. Hydoxyl radical $\left(\mathrm{OH}^{\circ}\right)$ formed by the HaberWeiss reaction in the presence of $\mathrm{H}_{2} \mathrm{O}_{2}$ and iron ions is the most biologically active free radical and is formed in vivo under hypoxic conditions. It can reduce disulfide bonds in proteins resulting in their unfolding and scrambled misfolding into abnormal spatial configuration. ${ }^{7}$

For this eventuality, a system of enzymes has evolved in cells to curtail the overreaching impact of ROS. However, the efficacy of these antioxidant enzymes, namely, superoxide dismutases, glutathione peroxidase and catalase, are sometimes compromised, or fall short of adequately disarming the immediate threat of ROS. ${ }^{8}$ This challenge gives credence to the inclusion of exogenous antioxidants in anti-stress therapies.

Over the years, medicinal plants have provided an inexhaustible store of antioxidants, some of which have been approved by the Food Drug Administration (FDA). Popular examples currently in use include, epigallocatechin-gallate, curcumin, quercetin and resveratrol, to mention but a few. ${ }^{9}$ With their high therapeutic efficiency and low toxicity profile as the most endearing characteristics, scientists have continued to screen plants for potential antioxidant drug candidates.

Newbouldia laevis (P. Beauv), native to tropical Africa is a medium sized plant which belongs to the family

Cite this article: Salemcity AJ, Nwaneri-Chidozie VO, Adameh E, Effiong ME. Antioxidant and Free Radical Scavenging Activity of Newbouldia laevis Leaf extracts (in vitro). Free Radicals and Antioxidants. 2020;10(1):10-5. 
Bignoniaceae. It grows to a height of about 7-8 metres. ${ }^{10}$ Its effect on a number of disease conditions where oxidative stress is implicated has been assessed. Its anti-inflammatory properties as well as its use in the treatment of epilepsy and convulsion in children are well documented. ${ }^{11}$ It have demonstrated the sedative effects of the methanol leaf extracts in mice and rats. The antimalarial and antimicrobial potencies of the root extract were reported as well as the anti-diabetic property of the leaf extract. The apparent therapeutic efficacy in these conditions may depend on the inherent antioxidant properties of NL extracts. This study was designed to evaluate the antioxidant properties of NL extracts in in vitro studies.

\section{MATERIALS AND METHODS}

\section{Collection and identification of plants}

The leaf of Newbouldia laevis was collected from Anyigba, Kogi State and was authenticated by a taxonomist in the Herbarium Unit, Salem University Lokoja, Kogi State with Voucher Specimen Number SU11012.

\section{Extraction}

The leaves of Newbouldia laevis were dried at room temperature (28$30^{\circ} \mathrm{C}$ ) for four $(4)$ weeks and pulverized to a fine powder using a blender. The extract was obtained by cold extraction with methanol in 1:10 (w/v) ratio. After thorough mixing, it was allowed to stand for $72 \mathrm{hr}$ and filtered using sterile Whatman No 1 filter paper.

The green colour filtrate (extract) was concentrated using rotary evaporator. The resulting crude extract was evaporated to dryness in a water bath. The crude methanol extract was then partitioned successively between $\mathrm{n}$-hexane, chloroform and distilled water using vacuum liquid chromatography (VLC).

\section{Experimental animals}

10 healthy male albino rats weighing $130 \mathrm{~g}$ each were purchased from Salem University's animal house. The animals were housed under standard laboratory conditions of light, temperature and humidity. They were allowed to acclimatize for one week. The animals were given free access to standard rat chow and water.

\section{Antioxidant activity assay}

The total antioxidant activity of the extracts was evaluated by the phosphomolybdenum method of Prieto et al. ${ }^{12}$ Exactly $0.3 \mathrm{ml}$ of plant extract was combined with $3 \mathrm{ml}$ of reagent solution $(0.6 \mathrm{M}$ sulfuric acid, $28 \mathrm{mM}$ sodium phosphate and $4 \mathrm{mM}$ ammonium molybdate). The tubes containing reaction solution were incubated at $95^{\circ} \mathrm{C}$ for 90 min. Then the absorbance of the solution was measured at $695 \mathrm{~nm}$ using spectrophotometer against blank after cooling to room temperature. Ascorbic acid was used as reference standard. The antioxidant activity is expressed as the number of equivalents of ascorbic acid (AscAE).

\section{Total phenol content}

The total phenolic content was determined using a spectrophotometric method described by Singleton et al. ${ }^{13}$ A reaction mixture containing $0.5 \mathrm{ml}$ ethanol solution, $1 \mathrm{mg} / \mathrm{ml}$ extract, $2.5 \mathrm{ml} \mathrm{10 \%} \mathrm{Folin-Ciocalteu's}$ reagent and $2.5 \mathrm{ml} 7.5 \% \mathrm{NaHCO}_{3}$ was incubated at $45^{\circ} \mathrm{C}$ for $15 \mathrm{~min}$. The absorbance was determined at $765 \mathrm{~nm}$. The same procedure was repeated for ascorbic acid and a standard curve was constructed. The total phenolic content was expressed in terms of ascorbic acid equivalent (mg of AscA/mg of extract).

\section{1, 1- diphenyl-2-picryl-hydrazyl (DPPH) free radical scavenging assay}

The free radical scavenging activity of the extract was measured using DPPH free radical scavenging assay. ${ }^{14}$ Exactly $0.1 \mathrm{mM}$ solution of DPPH in methanol was prepared from which $1 \mathrm{ml}$ was added to $3 \mathrm{ml}$ of various concentrations $(0.2$ to $1.0 \mathrm{mg} / \mathrm{ml})$ of sample and incubated for $30 \mathrm{~min}$. Absorbance was determined at $517 \mathrm{~nm}$ using Ascorbic acid as a standard. The scavenging activity was calculated as follows:

DPPH radical scavenging activity $(\%)=[($ Abs control - Abs sample $) /$ Abs control] $\times 100$

\section{Hydrogen Peroxide Scavenging Capacity}

The hydrogen peroxide scavenging capacity was determined according to the method of Ruch et al. ${ }^{15}$ A solution of hydrogen peroxide (40 $\mathrm{mM}$ ) was prepared in phosphate buffer ( $\mathrm{pH} 7.4)$. Extracts $(100 \mu \mathrm{g} /$ $\mathrm{mL}$ ) dissolved in distilled water were added to $0.6 \mathrm{~mL}$ of the hydrogen peroxide solution. Absorbance was taken at $230 \mathrm{~nm}$ after $10 \mathrm{~min}$ against a blank solution containing the phosphate buffer only.

$\%$ scavenged $\left[\mathrm{H}_{2} \mathrm{O}_{2}\right]=[($ Abs control - Abs sample $) /$ Abs control $] \times 100$

\section{Preparation of tissue homogenate for lipid peroxidation} assay

Liver from albino rats were excised after sacrifice, washed with cold normal saline to remove excess blood, weighed and stored immediately at $-4^{\circ} \mathrm{C}$. The liver was homogenized in a $0.25 \mathrm{M}$ sucrose solution. The homogenate was centrifuged at $3000 \mathrm{rpm}$ for $10 \mathrm{~min}$ and the supernatant decanted into sample bottles and refrigerated for further use.

\section{Lipid peroxidation assay}

Thiobarbituric acid reacting substances (TBARS) in tissue was estimated by the method of Torres et al. ${ }^{16}$ This assay is based on the principle that at low $\mathrm{pH}$ and high temperature malondialdehyde binds TBARS to form a pink complex that can be measured at $535 \mathrm{~nm}$. Precisely $2 \mathrm{ml}$ each of thiobarbituric acid (TBA) and trichloro acetate (TCA) were added to $50 \mu \mathrm{l}$ of the tissue homogenates. The mixture was incubated for $30 \mathrm{~min}$ at $80^{\circ} \mathrm{C}$. The tubes were centrifuged at $3000 \mathrm{rpm}$ for $15 \mathrm{~min}$ after cooling. The supernatant was measured spectrophotometrically at a wavelength of $535 \mathrm{~nm}$.

\section{Vitamin C determination}

This method determines the vitamin $\mathrm{C}$ concentration in a solution by a redox titration using iodine..$^{17}$ As the iodine is added during the titration, the ascorbic acid is oxidized to dehydroascorbic acid, while the iodine is reduced to iodide ions.

Ascorbic acid $+\mathrm{I}_{2} \rightarrow 2 \mathrm{I}^{-}+$Dehydroascorbic acid

Due to this reaction, the iodine formed is immediately reduced to iodide in the presence of ascorbic acid. Once all the ascorbic acid has been oxidized, the excess iodine is free to react with the starch indicator, forming the blue-black starch-iodine complex. This is the endpoint of the titration.

Briefly, $0.005 \mathrm{~mol} \mathrm{~L}^{-1}$ iodine solution was prepared by dissolving $2 \mathrm{~g}$ and $1.3 \mathrm{~g}$ of iodine in $1000 \mathrm{ml}$ of distilled water. A Starch indicator solution, $(0.5 \%)$ was prepared by adding $0.25 \mathrm{~g}$ of soluble starch in $50 \mathrm{~mL}$ of near boiling water in a $100 \mathrm{~mL}$ conical flask. Solution was cooled before use.

About $20 \mathrm{ml}$ of the aliquot sample solution was pipetted into a $250 \mathrm{ml}$ conical flask and $1 \mathrm{ml}$ of starch indicator was added to the solution. This was titrated against a $0.005 \mathrm{~mol} / \mathrm{L}$ iodine solution until a permanent trace of a dark blue colour due to the starch - Iodine complex was observed 
and this was taken as the end-point. The titration was repeated until a concordant result of just $0.1 \mathrm{ml}$ interval was obtained.

\section{Calculation}

Vitamin C content $=\underline{\text { Weight of unknown Vitamin C }}$ Weight of sample taken$$
1
$$

Weight of unknown Vitamin C = Titre value x 1.76

\section{RESULTS}

\section{Total Antioxidant assay and Phenolic content}

The antioxidant activity and total phenol content of the extracts are illustrated in Figure 1 as equivalents of ascorbic acid. It was observed that the MENL had the highest antioxidant activity (1.776 \pm 0.01$)$, significant at $p<0.05$, while the CFNL and AFNL recorded $1.603 \pm 0.01$ and $1.558 \pm 0.02$ respectively. Phenolic contents of the MENL and CFNL were also higher than in the AFNL, however the CFNL recorded 3.198 \pm 0.01 , which is slightly higher than the $3.181 \pm 0.04$ recorded for the MENL. These differences are however insignificant.

\section{Hydrogen Peroxide Scavenging Assay}

Figure 2 shows the hydrogen peroxide scavenging activity of the extracts of $\mathrm{NL}$ at varying concentrations $(100-400 \mu \mathrm{g} / \mathrm{ml})$. The $\mathrm{H}_{2} \mathrm{O}_{2}$ scavenging property of the methanol extract rose steadily, attaining the highest inhibitory capacity of $44.5 \%$ at $400 \mu \mathrm{g} / \mathrm{ml}$. Of the three samples, the chloroform fraction had the least reducing power, most effective (43\%) only at $300 \mu \mathrm{g} / \mathrm{ml}$ and showing a sharp drop in activity at $400 \mu \mathrm{g} / \mathrm{ml}$.

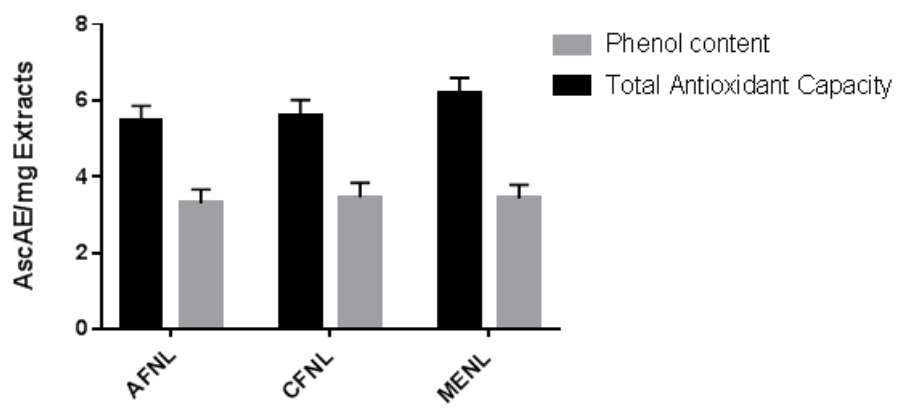

Figure 1: Total antioxidant capacity and phenol content of Newbouldia laevis leaf extracts.

Values are means of three readings \pm Standard deviation. $a, b p<0.05$ when compared to AFNL and CFNL respectively. Values are means of three readings \pm Standard deviation

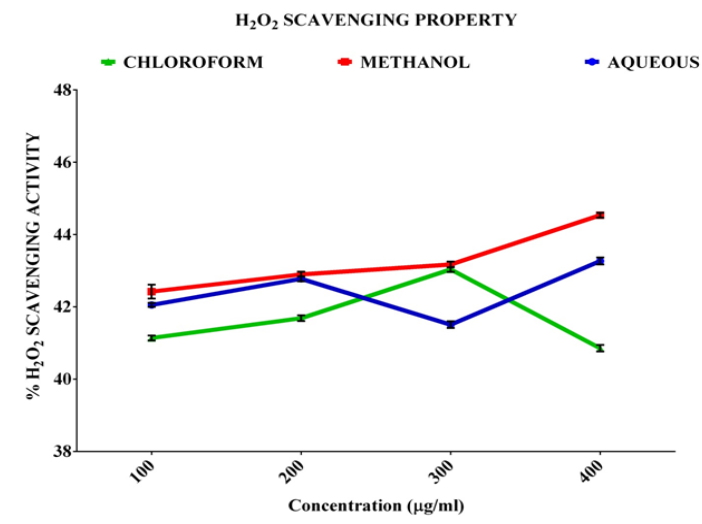

Figure 2: The $\mathrm{H}_{2} \mathrm{O}_{2}$ scavenging property of Newbouldia laevis leaf extracts.
There are no significant differences $(p<0.05)$ between the effects of the solvent fractions.

\section{1, 1- diphenyl-2-picryl-hydrazyl (DPPH radical scavenging activity)}

The percentage DPPH radical scavenging activity of the extracts of NL in comparison with same concentrations of ascorbic acid is represented in Figure 3. The methanol extract recorded an increasing radicalscavenging activity in a concentration dependent manner, with the highest activity of $76.4 \%$ at $400 \mu \mathrm{g} / \mathrm{ml}$. The chloroform fraction attained the highest activity $(63 \%)$ at $300 \mu \mathrm{g} / \mathrm{ml}$, while the aqueous fraction had the least activity of the three. However, across all the concentrations used in this experiment, none of the extracts used had as much activity as the standard antioxidant, ascorbic acid recording $87.9 \%$ at $400 \mu \mathrm{g} / \mathrm{ml}$.

\section{Lipid Peroxidation}

The effect of the extracts of NL was assessed in $\mathrm{Fe}^{2+}$-induced lipid peroxidation in rat liver tissue homogenate and as presented in Figure 4, the three extracts of NL inhibited peroxidation at all concentrations. The methanol extract had minimal inhibitory effects at lower concentration, but rose sharply at 50 and $100 \mu \mathrm{g} / \mathrm{ml}$ concentrations having $13.4 \%$ and $19.5 \%$ inhibition respectively. The effect of the chloroform fraction increased in a concentration dependent manner attaining a $19.03 \%$

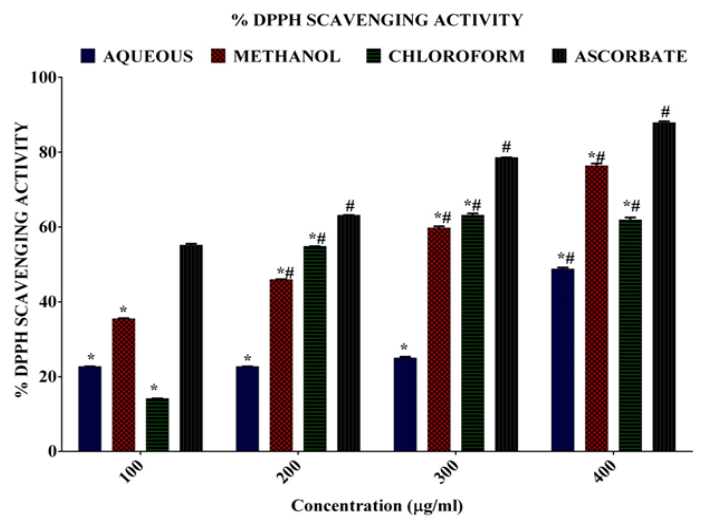

Figure 3: Percentage DPPH scavenging activity of Newbouldia laevis leaf extract.

( ${ }^{*} p<0.05$ when compared to the aqueous extract; $\# p<0.05$ when compared to the $\%$ DPPH Scavenging Activity at $100 \mu \mathrm{g} / \mathrm{ml}$ ).

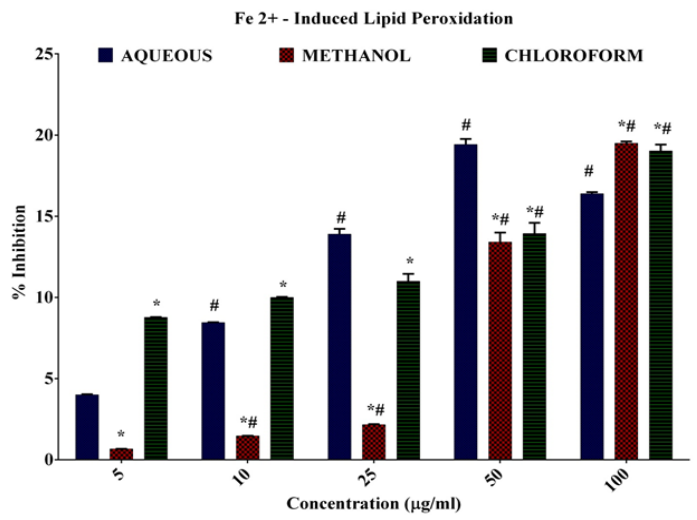

Figure 4: Effect of Newbouldia laevis leaf extracts on $\mathrm{Fe}^{2+}$-induced lipid peroxidation.

$\left({ }^{*} p<0.05\right.$ when compared to the aqueous extract; $\# p<0.05$ when compared to the $\%$ Inhibition at $5 \mu \mathrm{g} / \mathrm{ml}$ ). 


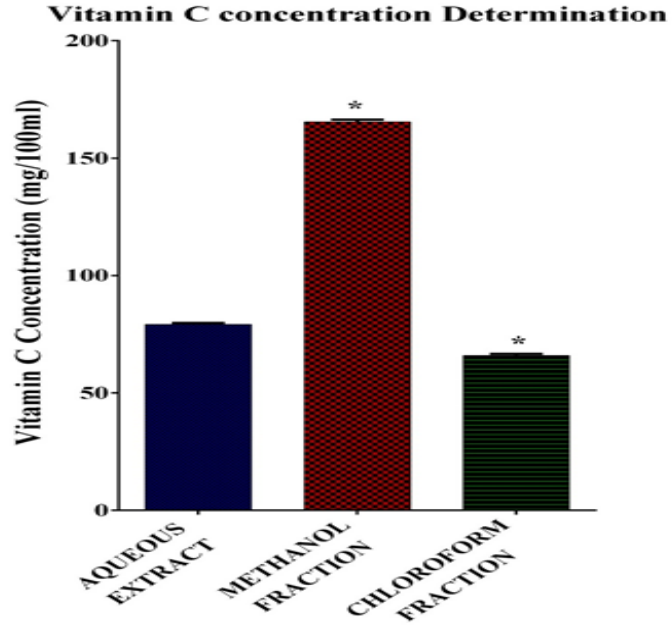

Figure 5: Vitamin C concentration determination.

${ }^{*} p<0.05$ when compared to the Vitamin $C$ concentration of the aqueous extract).

inhibition at $100 \mu \mathrm{g} / \mathrm{ml}$, while the aqueous fraction had its highest effect, $19.4 \%$ at $50 \mu \mathrm{g} / \mathrm{ml}$ followed by a slight drop to $16.39 \%$ at $100 \mu \mathrm{g} / \mathrm{ml}$.

\section{Vitamin C Content Determination}

Vitamin C, more properly called ascorbic acid, is an essential antioxidant needed by the human body. The experiment to determine Vitamin $\mathrm{C}$ levels in the different solvent fractions of NL leaf (Figure 5) shows that the methanol crude had the highest vitamin $\mathrm{C}$ concentration at $166 \mathrm{mg} / 100 \mathrm{ml}$.

\section{DISCUSSION}

A free radical is a molecule with an unpaired electron which is involved in lung damage, inflammation, reperfusion injury, cancer, cardiovascular disorders, atherosclerosis, aging and neoplastic diseases ${ }^{18}$ They are also involved in autoimmune disorders like rheumatoid arthritis. ${ }^{19}$ Many studies have investigated the role of antioxidant drugs and plant-derived compounds in the prevention of oxidative stress. ${ }^{20}$ Evidence from our results, has shown that Newbouldia laevis also contains compounds with antioxidant potential.

Medicinal plants are a good source of natural antioxidants. ${ }^{11}$ Belonging to this group are the antioxidant phenolics and flavonoids which have been reported to provide a form of defense against the debilitating effects of free radicals. ${ }^{21}$ From the total antioxidant capacity results shown in Figure 1, the methanol extract of NL exhibited a significantly higher antioxidant capacity than the chloroform and aqueous fractions. This may result from the fact that the crude contained all the phytochemicals and probably not chelated from activity. The appreciable antioxidant capacity of the chloroform fraction may be due to the presence of flavonoids as they can be extracted by chloroform. ${ }^{22}$ Phenolic compounds are very important plant constituents because their hydroxyl groups confer free radicals scavenging ability and this has been discovered to be richly present in extracts of NL (Figure 1). The therapeutic properties of NL leaves may not be unconnected to its rich phenolic content.

DPPH radical is essentially used for the evaluation of antioxidant activity. Based on the theory that antioxidants donate hydrogen ions, DPPH. (purple) accepts hydrogen and is converted to DPPH (yellow). Overall, the extracts of NL had a concentration-dependent DPPH• scavenging activity (Figure 2). While the three extracts showed varying magnitudes of antioxidant activity, the methanol extract had the highest scavenging activity $(76.64 \%)$ at the concentration of $400 \mu \mathrm{g} / \mathrm{ml}$, comparing well with ascorbic acid. There is a positive correlation between the scavenging effect of plant extracts on DPPH and the phenolic concentration of the extracts. ${ }^{23,24}$ which is believed to contribute to their hydrogen donating ability. It could therefore be suggested that MENL contains flavonoids with hydroxyl groups that could stabilize free radicals.

Hydrogen peroxides in human physiology are not primarily harmful, however, its toxicity has been reported to come from its tendency to produce hydroxyl radicals $\left(\mathrm{OH}^{*}\right)$ through the Fenton reaction. Hydroxyl radicals are highly reactive, propagating oxidative stress in vivo. ${ }^{25,26}$ The methanol fraction recorded the highest scavenging ability of the three extracts having $44.5 \%$ capacity at $400 \mu \mathrm{g} / \mathrm{ml}$, while the other fractions at this concentration had a lower effect. These results imply that the extracts of NL inhibit the formation of hydroxyl radicals and further highlights the antioxidant potential of the extracts of NL.

In the present study, the observed results (Figure 4) showed NL has the ability to inhibit lipid peroxidation. The methanol extract had the highest inhibitory effect at $100 \mu \mathrm{g} / \mathrm{ml}$. Studies have reported a significant relationship between the inhibitory effect of plant extracts on lipid peroxidation. ${ }^{27}$ and their antioxidant or reductive properties. ${ }^{28}$ With the methanol extract again demonstrating the highest inhibitory property, its activity may therefore be dependent on the antioxidant properties of its composition. It is also a pointer to the fact that utilization of this plant for management or treatment of ailments, is not harmful to the cells.

Ascorbic acid (Vitamin C) plays an important role in immune system maintenance and in a range of biosynthetic processes such as neurotransmitter and collagen synthesis. In general, it acts as an enzyme cofactor, free radical scavenger and donor and acceptor in electron transfer reactions. ${ }^{29}$ Vitamin $\mathrm{C}$ is considered the most important watersoluble antioxidant in extracellular fluids. It is capable of neutralizing ROS in the aqueous phase before lipid peroxidation is initiated. Vitamin E, a major lipid-soluble antioxidant, is the most effective chain-breaking antioxidant within the cell membrane where it protects membrane fatty acids from lipid peroxidation. The ability of Vitamin $\mathrm{C}$ to regenerate vitamin $\mathrm{E}$ following its oxidation has highlighted its physiological importance. ${ }^{30}$ This study revealed the presence of Vitamin C in the extracts of NL, with the methanol extract displaying the highest content. This highlights the potential of NL as a source of bioactive ingredients for the treatment of stress related ailments.

\section{CONCLUSION}

Plant extracts are a cocktail of phytochemicals, each with its inherent chemistry and potential biochemical importance. A broad range of methods are usually deployed at assessing these properties to give insight on the probable mechanisms of action, especially when a further study is being proposed. This research has provided useful information that shows that Newbouldia laevis can inhibit lipid peroxidation, has high Vitamin $\mathrm{C}$ content, significant antioxidant activity and high phenol content. The plant leaf also scavenged free radicals as tested by DPPH scavenging assay and hydrogen peroxide assay. The extracts of Newbouldia laevis leaf could thus find important application in producing excellent chemotherapeutic and phytotherapeutic agents against diseases associated with oxidative stress. However, experiments confirming these activities of the extract of Newbouldia laevis in an in vivo system would be necessary. If the results of such experiments agree significantly with the in vitro results, then it would be easy to make inference that Newbouldia laevis extract would prevent oxidative damage to macromolecules.

\section{ACKNOWLEDGEMENT}

We appreciate the pleasure of Prof. S. Awe for allowing this work to be done in one of his laboratories. We also express our profound gratitude 
to the Technologist, Mr. Ernest, who co-operated in supplying some of the reagents needed.

\section{CONFLICT OF INTEREST}

The authors declare no conflict of interest and state that no similar work has been submitted or published by another journal. This work has not been submitted or published elsewhere.

\section{ABBREVIATIONS}

NL: Newbouldia laevis; CFNL: Chloroform fraction Newbouldia laevis; AFNL: Aqueous fraction Newbouldia laevis; MENL: Methanol fraction Newbouldia laevis.

\section{REFERENCES}

1. Ferroni P, Barbanti P, Della-Morte D, Palmirotta R, Jirillo E, Guadagni F. Redox mechanisms in migraine: Novel therapeutics and dietary interventions. Antioxid Redox Signal. 2018;28(12):1144-83

2. Joanna K, Hassan Y, Aboul-Enein, Aleksandra K, Jacquelyn E. Bowser. Oxidative stress in biological systems and its relation with pathophysiological functions: The effect of physical activity on cellular redox homeostasis. Free Radic Res. 2019;53(5): 497-521.

3. Brookes PS, Yoon Y, Robotham JL, Anders M, Sheu SS. Calcium, ATP and ROS: A mitochondrial love-hate triangle. Am J Physiol Cell Physiol. 2004;287(4):C81733.

4. Picard M, McEwen BS. Psychological stress and mitochondria: A systematic review. Psychosomatic Med. 2018;80(2):141-53.

5. Guzy RD, Schumacker PT. Oxygen sensing by mitochondria at complex III: The paradox of increased reactive oxygen species during hypoxia. Exp Physiol. 2006; 91(5):807-19.

6. Merry TL, Wadley GD, Stathis CG, Garnha AP, Rattigan S, Hargreaves M, et al. N-Acetylcysteine infusion does not affect glucose disposal during prolonged moderate-intensity exercise in humans. Journal Physiol. 2010;588(9):1623-34.

7. Lipinski B. Hydroxyl radical and its scavengers in health and disease. Oxidative Medicine and Cellular Longevity. 2011;1-9

8. Simioni C, Zauli G, Martelli AM, et al. Oxidative stress: Role of physical exercise and antioxidant nutraceuticals in adulthood and aging. Oncotarget. 2018;9(24): 17181-98.

9. Kawamura T, Muraoka I. Exercise-induced oxidative stress and the effects of antioxidant intake from a physiological viewpoint. Antioxidants. 2018;7(9):119.

10. Arbonnier M. Trees, shrubs and lianas of West African dry zones. Editions Quae. 2004

11. Iwu MM, Gbodossou E. The role of traditional medicine. The Lancet. 2000;356:S3.

12. Prieto $P$, Pineda M, Aguilar M. Spectrophotometric quantitation of antioxidant capacity through the formation of a phosphomolybdenum complex: Specific application to the determination of Vitamin E. Anal Biochem. 1999;269:337-41.
13. Singleton VL, Orthofer R, Lamuela-Raventós RM. Analysis of total phenols and other oxidation substrates and antioxidants by means of folin-ciocalteu reagent. Methods Enzymol. 1999;299:152-78.

14. Molyneux P. The use of the stable free radical diphenylpicrylhydrazyl (DPPH) for estimating antioxidant activity. Songklanakarin J Sci Technol. 2004;26(2):211-9.

15. Ruch RJ, Crist KA, Klaunig JE. Effects of culture duration on hydrogen peroxideinduced hepatocyte toxicity. Toxicol Appl Pharmacol. 1989;100(3):451-64.

16. Torres RL, Torres I, Gamaro G, Fontella FU, Silveira PP, Moreira JSR, et al. Lipid peroxidation and total radical-trapping potential of the lungs of rats submitted to chronic and sub-chronic stress. Braz J Med Biol Res. 2004;37(2):185-92.

17. Nweze $\mathrm{C}$, Abdulganiyu $\mathrm{M}$, Erhabor $\mathrm{O}$. Comparative analysis of Vitamin $\mathrm{C}$ in fresh fruits juice of Malus domestica, Citrus sinensi, Ananas comosus and Citrullus lanatus by iodometric titration. Int J Sci Environ Technol. 2015;4(1):17-22.

18. Thomas JP, Kalyanaraman B, Girotti AW. Involvement of preexisting lipid hydroperoxides in Cu2+-stimulated oxidation of low-density lipoprotein. Arch Biochem Biophys. 1994;315(2):244-54

19. YuY, Gao Q, Xia W, et al. Association between physical exercise and biomarkers of oxidative stress among middle-aged and elderly community residents with essential hypertension in China. BioMed Res Int. 2018;4135104.

20. Madhavan J, Grieser F, Ashokkumar M. Combined advanced oxidation processes for the synergistic degradation of ibuprofen in aqueous environments. J Hazardous Materials. 2010;178(1-3):202-8.

21. Matkowski A. Plant phenolic metabolites as antioxidants and mutagenesis inhibitors. Cell Biology and Instrumentation: UV Radiation, Nitric Oxide and Cell Death in Plants. 2006;129-48.

22. Hossain MA, Shah MD. A study on the total phenols content and antioxidant activity of essential oil and different solvent extracts of endemic plant Merremia borneensis. Arabian J Chem. 2015;8(1):66-71.

23. Sen S, De B, Devanna N, Chakraborty R. Total phenolic, total flavonoid content and antioxidant capacity of the leaves of Meyna spinosa Roxb., an Indian medicinal plant. Chin J Nat Med. 2013;11(2):149-57.

24. Das N, Islam ME, Jahan N, Islam MS, Khan A, Islam MR, et al. Antioxidant activities of ethanol extracts and fractions of Crescentia cujete leaves and stem bark and the involvement of phenolic compounds. BMC Complement Med Ther. 2014;14(1):45.

25. Ogasawara $Y$, Imase M, Oda H, Wakabayashi H, Ishii K. Lactoferrin directly scavenges hydroxyl radicals and undergoes oxidative self-degradation: A possible role in protection against oxidative DNA damage. Int J Mol Sci. 2014;15(1):1003-13.

26. Song JL, Choi JH, Seo JH, Kil JH, Park KY. Antioxidative effects of fermented sesame sauce against hydrogen peroxide-induced oxidative damage in LLCPK1 porcine renal tubule cells. Nutr Res Pract. 2014;8(2):138-45.

27. Adesanoye O, Farombi E. In vitro Antioxidant Properties of Methanolic Leaf Extract of Vernonia Amygdalina Del. Niger J Physiol Sci. 2014;29(2):93-101.

28. Akinmoladun AC, Obuotor EM, Farombi EO. Evaluation of antioxidant and free radical scavenging capacities of some Nigerian indigenous medicinal plants. $J$ Med Food. 2010;13(2):444-51.

29. Agius F, González-Lamothe R, Caballero JL, Muñoz-Blanco J, Botella MA Valpuesta V. Engineering increased Vitamin $\mathrm{C}$ levels in plants by overexpression of a D-galacturonic acid reductase. Nature Biotech. 2003;21(2):177-81.

30. Traber MG, Sies H. Vitamin E in humans: Demand and delivery. Annu Rev Nutr. 1996; 16:321-47.

\section{GRAPHICAL ABSTRACT}

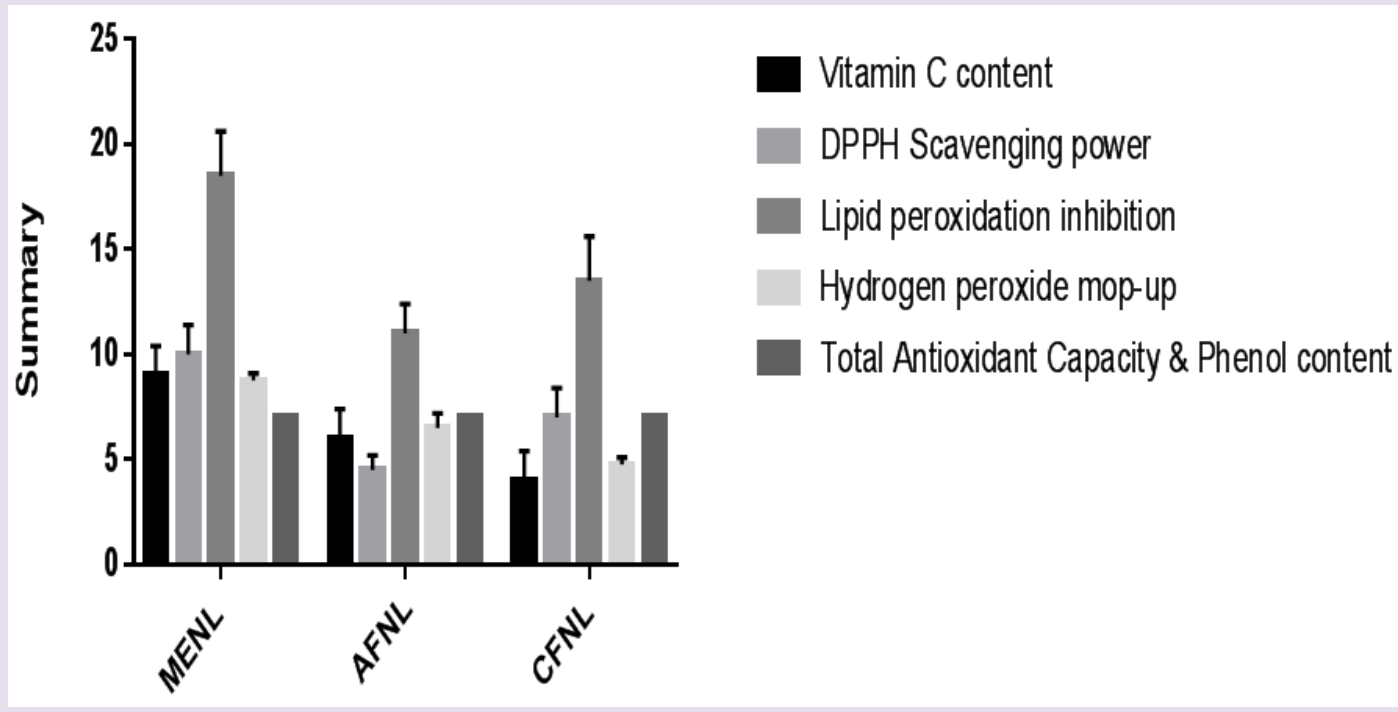




\section{ABOUT AUTHORS}

Aanuoluwa James Salemcity: $\mathrm{He}$ holds the conception of the idea of this research and editing of the manuscript.

Victoria Obiageli Nwaneri-Chidozie: She assisted in fine-tuning of the research methodology

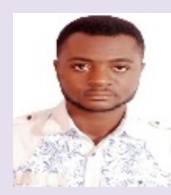

Emmanuel Adameh: He did the benchwork and analysis of the data collected

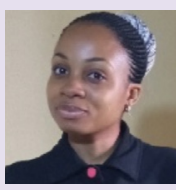

Magdalene Eno Effiong: She was involved in the write-up of this manuscript.

Cite this article: Salemcity AJ, Nwaneri-Chidozie VO, Adameh E, Effiong ME. Antioxidant and Free Radical Scavenging Activities of Newbouldia laevis Leaf extracts. Free Radicals and Antioxidants. 2020;10(1):10-5. 